\title{
MISCELLANEA
}

\section{The Health Hazards of the Senior Executive}

\author{
A. R. COOPER \\ Controller of the North West Merseyside and North Wales \\ Divisions of the British Electricity Authority
}

The health of a senior executive is essentially a matter for some concern, partly because of the direct effects on the executive himself but also, and probably chiefly, because of the indirect effects on the people under his control.

It is not implied that the decisions of a healthy executive are necessarily better than those of an unhealthy one, for there is no correlation, to my knowledge, between health and wisdom or health and moral values, but it does seem reasonable to assume that an executive will produce his best work if he is not bedevilled by sickness and that his mind will be better able to deal with the problems of his work if it is not being obsessed with real or imaginary troubles of his own.

Arising from these considerations we may ask ourselves how the daily life of the executive varies from the healthy norm (if there is such a standard) and what forms of illness are most frequently recurring with his type.

From the purely biological viewpoint his habits are almost directly opposed to those of a normal healthy animal. He is taken from place to place in a car and sits comparatively motionless throughout his working day. He eats and drinks and smokes far more than any man should and, if it is part of his business to be sociable and to mix pleasantly with people, he may find it very difficult to cut down on these things.

The only really active component in his make-up is his brain and this part of his anatomy is responsible both for controlling the functions of his body and the operation of his business. If the brain is having a very difficult time in dealing with the problems of his business it will not be surprising, at any rate to the layman, if it falls a little short of perfection in the way it handles his body.

The type of executive I had in mind when compiling these notes is the comparatively quiet, conscientious, painstaking man who makes it his business and almost his religion to ensure that the enterprise for which he is responsible shall not fail, that the people engaged in the enterprise shall live happy, creative lives, and that all those who have placed their confidence in his leadership shall never regret it.

The modern tendencies towards large-scale organizations, joint consultation, and worker participation in management have not tended to improve the health of the top executive. These new conditions call for much more self-control, patience, and what is sometimes referred to as " suppressed anger", than was experienced in the days when the manager was expected to "blow off his top " at regular intervals, and such neuroses as existed were allocated to the staff.

Knowing that this situation exists, the question arises, What can be done about it How can we produce a situation in which a senior executive will tend to be a healthy, efficient individual who is enjoying his work?

In the first place it will be necessary to ensure that he is capable of doing his job without undue stress. If a man accepts a job which is too big for him he will be neither happy nor efficient and as an end-product of these two conditions I would suggest that he is also likely to be unhealthy.

I mention this matter first as there are many men who are driven by overweening ambition, either their own or possibly that of their wives, into thinking that continued promotion is the only measure of success in life. It requires a man of strong character to refuse a promotion even if he knows that he is thoroughly unsuited to the new job. Probably the simplest illustration of this situation is that in which an outstandingly competent fitter is promoted to the rank of foreman in which capacity, instead of directing the work of his own hands, he has to direct the work of others. The result in this case and in others higher up the administrative hierarchy can frequently be disastrous both for the man and the organization. The remedy, as I see it, is for the man to recognize that there is some level appropriate to himself towards which he should strive in the knowledge that he would be rather ashamed to remain below that level and exceedingly unhappy if he tried to operate very far above it. There need be no sense of inferiority in holding any position lower than that of managing director if the aim is to live successfully rather than to struggle for the highest possible salary.

I have laboured this point a little for two reasons; first, because I think that much misery will come the way of people who are unhealthily ambitious, and, secondly, because I think that a competent executive can do much to allay these symptoms among his staff by treating them essentially as equals who happen to be doing different jobs rather than as the higher and lower forms of life which they may appear to be on the firm's organizational chart.

If now we assume that our executive is the right man for the job what factors emerging from the job are most likely to undermine his health?

I would suggest that frustration is one of the most important. Frustration occurs when action is prevented or impeded. It is usually at a minimum when the executive 
can make quick decisions, or when he can obtain quick decisions from others; it is at a maximum when no decisions even on minor matters can be made without lengthy negotiations and references back and forth with higher authorities. The remedy is to delegate authority while knowing that one cannot delegate responsibility. It needs courage on the part of top management and a realization on their part that any man who does a lot of things is certain to do some of them wrongly. The executive is happier and more efficient if he feels that the management are willing to take a chance on his judgment.

The next factor I would bring forward is the worrying or tension-provoking situation which can develop, often quite needlessly, in modern management. The normal ups and downs of any business concern must be accepted with reasonable equanimity (that is one of the qualifications for the job) but there are two major fears which can play havoc with the peace of mind not only of the executive but also with many members of the staff. They are the fear of insecurity and the fear of making mistakes.

Every man is concerned in some degree with the security of his employment. It can be argued that a man who knows his job is safe begins to deteriorate as a certain amount of apprehension is a necessary spur to his activities. This is probably true, but it is also true that no man can give of his best if a series of ruthless dismissals keeps him wondering who goes next and if half his energies are concentrated on looking for other jobs. The solution to this problem is essentially a matter for top management, but it should be appreciated that the climate of opinion which their administration produces can have a significant bearing on the health of the people concerned.

Secondly, there is the fear of doing something wrong. This can become such a powerful disincentive that it can inhibit all those adventuresome and original sorties by which the executive uses his creative genius for the benefit of the firm. He becomes like a batsman whose wicket will never be hit but who will never score any runs. This again is essentially a matter which concerns top management, except that the executive must realize the need to apply lower down the scale the same treatment which we are assuming should be accorded to him.

In all I have so far said I have made no reference to the part which can and probably should be played by the industrial medical officer in these matters. I have deliberately treated the executive as an isolated individual and attempted to indicate some of the forces with which he has to contend in order that the industrial medical officer in recognizing causes will find it a little easier to discover cures.

One thing probably more important to the executive's health than any other, especially if he has no recognized deputy, is that he should have some person to whom he can talk confidentially about anything. Emotional stresses and the inhibitions which may flow from them can often be relieved if the executive can talk about his problems to some person such as the industrial medical officer. He will through force of habit want to talk about his aches and pains, but if he can also talk about the difficulties he is having with $\mathrm{A}$ or the troubles which are being caused by disagreements between $B$ and $C$ he will find first, that the answer to many a problem will appear once he has expressed that problem in words, secondly, that tension is relieved by talking about the subject, and thirdly, that the industrial medical officer's knowledge of the personality and emotional backgrounds of the people concerned can sometimes be a great help in working out satisfactory solutions. At this point I feel that I must for his own sake consider the significance of the industrial medical officer in the industrial scheme. It can so easily happen that because of his medical training and the "closed shop" atmosphere which old-fashioned members of the profession have helped to create, he may tend to be somewhat pontifical in his approach to less senior members of the staff and his freedom of association with top management will tend to accentuate this failing. It may be a useful if rather brutal corrective to this attitude to point out that many firms function quite successfully without an industrial medical officer and that even where they exist if a choice had to be made for reasons of economy between discharging either the industrial medical officer or a reasonably competent foreman, the industrial medical officer would almost certainly disappear. No harm will ensue if he carries this thought at the back of his mind, and if it results in his establishing a friendly, informal relationship with every member of the staff from the commissionaire to the general manager it will do much good. Humility of mind is, I think, the answer ; the ability to feel towards all members of the staff as an East End parson feels towards his flock, rather than as a country squire used to feel towards his tenants.

And I think that the health of the senior executive would also benefit from considerations of this nature, for I feel sure that an attitude of healthy humility on his part will go a long way towards the creation of a contented mind. 